Journal of Business \& Management (COES\&RJ-JBM)

ISSN (E): 2306-7179 ISSN (P): 2306-8043

Publisher: Centre of Excellence for Scientific \& Research Journalism, COES\&RJ LLC Online Publication Date \& Issue: 1st April 2017, Vol.5, No.2, April 2017

http://centreofexcellence.net/J/JBM/JBM\%20Mainpage.htm

\title{
The Monetary Policy and Function of the Central \\ Bank from an Islamic Financial Perspective
}

Ziad Mohammed Obeidat

The World Islamic Sciences \& Education University - Jordan

Yaser Abdelkarim Hourani

The World Islamic Sciences \& Education University -Jordan

Ashraf Jahmani

Al Falah University -Dubai- UAE

\begin{abstract}
:
This research aimed at concentrating on the functional roles that the central bank use in dealing with Islamic bank, and to reveal the shortcomings stemming from the censorship role imposed on the Islamic bank in the context of a comprehensive monetary policy. Then, the research focused on the roots of relationship between central bank and the Islamic bank, and the functions of the central bank. Furthermore, the research focused on some related aspects such as: the function of minimum legal reserves and its relation with Al-Zakat and the worthies of profit. Besides some functions like: the function of the central bank as a last resort lender, the policy of discount rate, the open market Operations, and evaluating these functions in the light of Islamic bank mechanisms .The results showed that it is necessary to adapt the central bank to some monetary tools in order to harmonize it with the provisions of Al SHAREIA such as: replacement the surplus of RIBA with accepted forms for the Islamic bank such as participation and venture, Besides, the contribution of Islamic bank in resolving some problems on the base of massive Islamic banking work process, i.e. through international banking channels, in order to decrease its dependence on the central bank inside one country as it is possible.
\end{abstract}

Keywords:

Monetary Policy, Islamic Banks, Legal Supervision

Citation:

Obeidat, Ziad Mohammed; Hourani, YaserAbdel karim; Jahmani, Ashraf (2017), The Monetary Policy and Function of the Central Bank from an Islamic Financial Perspective; Journal of Business \& Management (COES\&RJ-JBM) Vol.5, No.2, pp.83-101.

This work is licensed under a Creative Commons Attribution 4.0 International License. 


\section{Introduction:}

The central bank performs many functions that embody the state's policy and role in realizing the public interests of society through directing economic life activities and controlling its various sectors.

The importance of the research lies in identifying the size of interference and its capability to restrict some Islamic banking activities then attempting to introduce several perceptions and solutions to condition the relationship within the frame of Sharia provisions.

The most important role adopted by the central bank in this aspect is controlling the monetary policy and governing exchanges in commodity and cash markets in addition to other actions such as issuing banknotes and monitoring exchange rates and many other tasks and roles.

The monetary policy is one of the most important basic objectives of the central bank to maintain the soundness of the financial position of the financial institutions and protect them from the risks of bankruptcy especially under the repercussions of the international financial crisis.

In this respect, the central bank concentrates on controlling the banknote offer and monetary base by applying certain instruments namely the minimum statutory reserve, the discount rate mechanism, the role of lender of last resort and open market operations.

In applying those instruments on Islamic banks, many Problematic issues appear due to the repulsion between the legitimate formula applied by Islamic banks and the illegitimate formula applied by traditional banks.

The problem of the research is implied in the substantial differences concerning the interaction of the central bank with Islamic banks through the same censorial tools used with traditional banks with no consideration to the privacy of the Islamic banks which rule out usury.

Consequently, the research assumes that the annulment of usury is the touchstone of legal oversight which is based on a monetary policy that considers the particularity of the Islamic banks according to the approved legitimate principles.

The research is divided into four topics:

- $\quad$ First topic: the nature and development of the relationship between the central bank and the Islamic bank.

- $\quad$ Second topic: The importance of the central censorship over Islamic banks.

- $\quad$ Third topic: The requirements of the minimum statutory reserve.

- $\quad$ Fourth topic: Conditioning the Functions of the central bank with the Islamic bank`s policy.

1- $\quad$ The Nature and Development of the Relationship Between the Central Bank and the Islamic bank Including three subjects:

Islamic bank.

- $\quad$ Second subject: The nature of Censorship over the Islamic bank.

- $\quad$ Third subject: the scope of the central bank's relationship with the Islamic bank. 
1.1 The Nature and Orientation of the Interactive Performance of the Islamic Bank In spite of the novelty of the experience that accompanied the establishment of the Islamic bank in 1960s through the "local savings banks" it is still the real materialization of the participatory philosophy on which Islamic banking is based in contemporary life $^{2}$.

The process of expansion in the establishment of Islamic banks was accompanied by increasing interest in rooting banking thoughts in accordance with the Islamic legislation. Banking activity expanded to include many formats such as murabaha Sales, speculation, participation, leasing and leases ended with ownership and others, until big issues produced by the Islamic financial engineering invention transpassed the basic aspects of legal debates to reach at what is known by benefit lease, distribution of return on investment, corporate governance, stock markets and other similar practices ${ }^{3}$.

Here, it is important to praise the banking project of an integral economic model which was presented by the council of Islamic Thought in Pakistan as a banking model that does not apply interest rate.

The functional structure of the Islamic bank system extended to a vast geographical area and some countries like Iran, Pakistan and Sudan ${ }^{4}$ moved to the Islamization of the whole banking system, However, with the presence of such qualitative and quantitative spread, there are fundamental issues that reflect growing significance to confront, like harmonizing the censorship over the Islamic banks whether on the level of legal control or banking control, asserting the social role of the Islamic bank, realizing the goals of social welfare, achieving the objectives of development according to legislative non - usurious foundation, avoiding investment formula that contradicts the verdicts of jurisprudential council and most importantly, attempting to discard the interests of profit maximization on account of social benefits.

\subsection{The Nature of Censorship over the Islamic Bank}

Many censorial forms are practiced over the Islamic bank: Administrative, legislative, banking and legal. In fact, the Islamic bank is facing problems in banking work relations to organize all those forms of censorship.

The board of directors and its relevant administrative authorities are in charge of the administrative censorship In many cases, the role of shareholders represented in the general assembly is excepted or canceled from monitoring the administrative activity and recognizing the avail of managerial decision which are taken to protect the bank`s

\footnotetext{
${ }^{1}$. RizkRaidy, Arab Society in the Phase of Change, translated by Ahmad Abdil - Aziz Al - Najjar, ed. I . Al - Dar AlSudaniah, 1970, P 30.

2. Rafeeq Al - Masri, Islamic Development Bank, ed.3. Beirut. AL - Risalah establishment, 1987, p 325-326.

${ }^{3}$. All that was preceded by investigating the core concepts that connect the relationship of the Islamic bank with creed, morals, advocacy, Zakat and society development in addition to the Contribution of those banks in granting the good (Hassan) loans and financing small producers, productive poor families and craftsmen sectors and all what may contribute in participatory banking work.

4. Mohammad Uthman Al - Khalifah, "The Banking Model in Sudan between the non - usurious institution and the integral Islamic institution". Abhath Al - Iman journal, second year, No. 2, 1996, p 53.
} 
interests, which is all accomplished under an administrative cover that lacks the minimum level of clarity and transparency,

Legislative control is connected to the competence of the Sharia Supervisory Board. In this respect, the bank encounters difficulties in the duplicity of specialization of the Sharia Supervisory Board i.e the absence of jurists who are familiar with all the aspects and different procedures of banking and being content with the presence of a legal consultant in place of an integrated sharia supervisory board ${ }^{5}$. Moreover, the Islamic bank does not deal according to unified standards committed to Fatwa decisions issued by juristic boards and consequently, the legal formulas do not agree with each other among Islamic banks.

As for the banking and legal control, it is of the central bank's works and the individual or internal Control performed by shareholders can be annexed to it as they are originally the owners of the capital.

The most important side here is the legal control conducted by the state represented by the central bank. This control is justified by that the Islamic bank practices its activities in the frame of a sovereign state governed by its own law, constitution and legislations. In this aspect appear the functional problems of the Islam bank through the credit and monetary relations with the central bank, which will be clarified later. The central bank acquires its legality of interference as it represents the state's will in applying the law. It is widely known that the Islamic law gives the state the authority of maintaining the public interests. The substance of legal conditioning in this subject is based on what jurists call "legitimate Purposes" which means maintaining the five necessities ${ }^{6}$ and that the instruments of keeping and preserving them are of the strongest interests. Therefore, the interference of the central bank is a must to keep the money as an assertory interest urged by sharia.

However, the interference of the central bank in this domain is not restricted to money as its impact extends to achieve the objectives of an extensive economic development by directing investments in specific sectors, using the appropriate monetary tools in cases of economic expansion and contraction and considering the situations of social balance between the investors and savers and the like procedures ${ }^{7}$.

The imbalance in the Islamic bank's relations with the central bank can be attributed to the clear contradiction between the sharia supervision process and the legal supervision process as the first is derived from sharia origins while the latter is drawn from positive laws. For that reason, resurrecting such reality in which the Islamic banks originated lacking sharia data, requires serious consideration to deduce a more compatible relevance to the regulations and activities of non - usurious Islamic banks ${ }^{8}$.

No doubt that the attempt to find a banking relationship derived from real contemporary life within the frame of sharia provisions does not depend just on canceling the return on

\footnotetext{
5. Ahmad Salem Abdullah Milhem, Murabaha sale, ed. 1. Amman, Al - Risalah library, 1989, P 257.

6. Mohammad Bin Mohammad Al - Ghazali, Shifaa' Al - Ghalil, edited by Hamad Al - Kubaisi. Ed. Baghadad, Al

- Irshad press, 1971, p 207.

7. Mohammad Farouq Al - Nabhan, Researches iv Islamic Economy, ed.1, Beirut, Al - Risalah Foundation, 1986, p $122-125$.

${ }^{8}$. BabakrMuhideenqili, The Relationship of the central Bank to Islamic Banks. Money and Economy, No. 3, 1986, P16.
} 
capital or not dealing with usury, as the movement of the Islamic bank's activities are subject to organizational systems completely inspired from the usurious institutions' structures without conducting deep examination to the essential difference between the two directions.

Therefore, the situation of the Islamic banking establishment should be reorganized on the basis of new frames and structures that fit into the integrated and comprehensive nature of Islam ${ }^{9}$.

\subsection{The Scope of the Central Bank's Relationship With the Islamic Bank}

The relationship of the central bank with the Islamic bank is regarded as an external censorship which is a type of control practiced by the state over the administrations of the banks by competent agencies from which is the central bank, to monitor the administrative process, its validity and accuracy of its implementation as well as controlling the monetary policy as it is planned, organized and oriented ${ }^{10}$.

Under the international repercussions, the local central banks were affected by the pressure of the international community which excreted many relevant variables such as liberalization of exchange rate, expansion and overlap of markets, the increasing impact of international stock markets, monitoring financial markets and the flow of capitals across countries. All said variables and the like carry an international feature which cannot be overstepped by the monetary authorities of a national country. Undoubtedly, there are international institutions that support the activities of central banks by means of banking instruments that work as tuning indicators like The Basel Committee on Banking Supervision $(\mathrm{BCBS})^{11}$ which contributes in harmonizing the banking control of central banks according to certain criteria such as capital adequacy to indicate the soundness of the bank's financial position and the confidence of depositors in the process of deepening the Solvency of the bank. There is also the Bank of International Settlements (BIS) that works as a central bank for the central banks on the international level through maintaining the international monetary and financial stability. It has also other tasks such as appointing the value of currencies, determining gold prices and reorganizing the international banking activity. It also plays a significant role in determining the interest rates in the short and long run ${ }^{12}$.

\footnotetext{
9. Mohammad Uthman Al - Khalifah, "The Banking Model in Sudan Between the Non - Usurious Establishment and the Integral Islamic Establishment, ibid. 1996. P 56 - 57.

${ }^{10}$. Abdul - Rahman Bin Ibrahim Al - Dhyan. Management and Governance in Islam; Thought and practice. Ed. 3. P.H, Kingdom of Saudi Arabia, P 133.

11 . The committee consists of the group of ten industrialized countries under the supervision of BIS. It was formed in the city of Basel in Switzerland to face the mutual risks of which are the new risks such as settle ment and replacement risks, and it came as a result of the external debt aggravation in the countries which borrowed from international banks and them failed or lagged. Although the standards of this committee do not contain binding provision, they acquire strength from the reforming programs led by international institutions like the World Bank and the international monetary fund as they consider those standards and recommend their application.

12. Jean - Claude Trichet: Global governance today, BIS Review 56 / 2010, O 2
} 


\section{The Importance of Central Censorship Over Islamic Banks Includes three subjects:}

First subject: The importance of central banks' censorship.

- $\quad$ Second subject: The Contradiction of the legal interference of the central bank.

- $\quad$ Third subject: Forms of Islamic institutional support to central banks.

\subsection{The Importance of Central Banks' censorship}

The importance of central banks' censorship on the banking sector, including the Islamic banks, appear through realizing a number of key goals the most important of which:

- $\quad$ Developing banking performance, following up the most optimal use of financial resource $^{13}$ and monitoring the flawlessness of the financial situation in the frame of the bank's relationship with clients.

- $\quad$ Paying more attention to the location and stature of the bank in front of its clients and other sides of interest like shareholders and investors as well as backing the bank's position against other local supervising bodies.

- $\quad$ Predicting the potential changes in the future performance level and dealing with them in the light of previous experiences in order to avoid them ${ }^{14}$.

- The ability to discover the gaps which occurred because of underacting, trespassing or malpractice and specifying the factors and administrative levels that affected them.

- $\quad$ Enhancing and directing banking policies management towards the solutions that are capable of correcting the critical situations and avoiding their reasons.

- $\quad$ Supplementing the actions of the other central authorities like central banks, boards of directors, Sharia supervisory boards and follow up and inspection bodies of the state because censorship in this concept is of the most important institutional governance tools that tune the relationships of Islamic banks with the internal and external environment.

Although the central bank's supervision over its banking responsibilities get into the state's duties and sovereignty in Keeping economic security, the central bank itself sometimes faces financial and economic disorders under its strict supervision on financial institution and banking activities; even the federal reserve system which supervises the banks and the monetary system in the United States of America notched great failure in treating three successive economic crises that led to hug retraction in the American economy. "Fredman" points out that the government shouldered this responsibility so unskillfully that turned what could have been moderate economic recession into an enormous economic disaster ${ }^{15}$.

Under the Islamic law, the state acquires the right to interfere within specific rules and warranties of which are achieving the objectives of public interest, Commitment to Sharia Purposes and following non - aggressive manner of interference ${ }^{16}$. This is because the individual is the core of interest in standardizing provisions, and releasing the will of the individual to develop their Personality depending on the principle of freedom which was

\footnotetext{
${ }^{13}$. Ghassan Kala' wi, Islamic Banks: Modern Necessity, why?, Beirut, Dar Al - Maktabi, 1998. P 267 - 268.

${ }^{14}$. Revsine. I. Collins, Financial Reporting and Analysis, New Jersey. 2005, P 121 - 137.

15. Milton Fredman, Capitalism and Freedom. Translated by yousefEliyan, Jordan book center, 1987, p39.

${ }^{16}$. Mohammad Farouq Al - Nabhan, Researches in Islamic Economy. Ibid, P 122 - 125.
} 
attended by Islam in organizing life affairs, "The treasury" - Bait Al - Mal - is an approximate image of the role of the central bank that allows the Islamic state to interfere in the monetary policy even though the economic roles it used to perform did not reach at the degree of complexity witnessed by the financial exchanges of contemporary life.

\subsection{The Contradiction of the Legal Interference of the Central Bank}

The Contradiction of the legal interference of the central bank in the Islamic bank goes back to its lack of a financial unit specialized in Islamic banking. The prevalent legal legislations do not distinguish, in the principle of censorship, between an Islamic bank and a non - Islamic bank which binds the Islamic bank to the same legal measures used with other banks.

Clearly, the Islamic bank is not commonly regarded as a commercial bank which mainly depends on demand deposits and other short term deposits. The mechanism contributes in recirculating and cashing money which affects the monetary base and offer, which is the center bank's specialty to control cash offer and credit policies. The Islamic banks are not considered commercial in this sense because they do not have the same impact on monetary offer, as most of the policies they adopt are participatory like industrialization, agriculturalization and participation ended with ownership and others ${ }^{17}$. Adding to that, the Islamic bank holds more risks in the field of investment between it and the depositor as the two sides share profit and loss.

Reconsidering the origin of legal censorship disorder gives way to the unification of the planned models by the central bank according to real banking activities maintained by the Islamic bank through adhering the legislative fatwa and transactions.

This necessitates exempting the Islamic bank from fixed reserve rates and the restrictions imposed its property of fixed and moveable assets where the potential of ricks caused by loans lessens especially that the Islamic bank is more capable to employ credit in a way that realizes the objectives of the central bank as a partner with the client in different investment aspects ${ }^{18}$.

\subsection{Forms of Islamic Institutional Support to the Central Banks}

On the Islamic level, there are Islamic institutions that support the work of central banks, the most important of which is the Accounting \& Auditing Organization for Islamic Financial Institutions (AAOIFI) which consists of non-founder members like the censoring and supervising agencies that supervise Islamic financial institutions including center banks and monetary institutions and the like"19. In this respect, AAOIFI covers all forms of supervision whether legislative, legal, accounting or banking by using various censorial instruments including the decisions of juristic boards, legal accounting and auditing companies, financial inventory users and monetary foundations represented by central banks. Although the standards of the organization are not binding, they turn to be

\footnotetext{
${ }^{17}$. Ismael Hasan , work paper about the relationship of the central bank with Islamic banks. Islamic economy, No.6,1985.

${ }^{18}$. kili, the relationship of the central bank with Islamic banks, Ibid, p 17

${ }^{19}$. View the thir article of the organizations modified basic system.
} 
so if adopted by central banks in the countries wherein Islamic banks act and recommend their application.

One of the significant standards developed by the accounting organization is the capital adequacy standard to be applied on Islamic banks. AAOIFI produced another accounting method for this standard under the supervision of the international settlements bank by incorporating new elements in the concept like investment accounts, sharing profits (partnership contracts) and other risks the Islamic banks are more familiar with than traditional banks ${ }^{20}$.

One of those Islamic bodies is also the Islamic Financial Services Board (IFSB) ${ }^{21}$ which issued international censorship standards that cope with the Islamic bank's activities. Those Standards are internationally recognized. Besides issuing those standards, the board is attempting to Condition international censorship standards in harmony with legal directives. The activities of the board are complementary to other international censorship organizations like Basel committee and the international banknote organization and others. In the period 2005 - 2012, IFSB established a number of international standards for Islamic banks like capital adequacy, risk management and cash risk management standards which all contribute in enhancing central banks' censorship on Islamic banks ${ }^{22}$.

\section{The Requirements of the Minimum Statutory Reserve Includes there subjects:}

- $\quad$ First subject: The concept and nature of the statutory reserve relation disorder.

- $\quad$ Second subject: The relation of the statutory reserve with Zakat.

- $\quad$ Third subject: Statutory reserve and due usurious increase.

\subsection{The Concept and Nature of the Statutory reserve Relation Disorder}

The central bank's law stipulates on all its subsidiary banks to put a minimum reserve in their safe deposit. The Purpose of this procedure is to face the incidental situations to protect the depositors' interests. This reserve takes the form of an immediate statutory balance to guarantee the deposits of clients. The Central bank usually resorts to using this reserve to affect the size of credit and monetary offer. In fact, imposing any increase on the statutory reserve requirements leads to weakening the capability of working banks to grant loans. Some banks may resort to the discount window in order to compensate the shortage in the reserve when they face Pressure as a consequence of buying binds in the open market operations.

The central bank has the capacity to use its full legal authority in changing the reserve rates. It can also practice its validities to change or discontinue the bank's activities if the depositors' interests are actually or almost exposed to real danger ${ }^{23}$. In case of changing the reserve rates, the central bank will be able to restrict time deposits with rates less thean demand deposits because of the difference in the degree of risk. Sometimes, higher reserve

\footnotetext{
${ }^{20}$. For more information, refer to Ahmed Al - Sayyad, risk managemer at Islamic banks. Conference of risk management at Islamic bank Amman, Arab Academy for financial and Banking Sciences, 2004, P11 -

${ }^{21}$. The board started its activities in 2003 in Malysia as an international body that cares for developing the Islamic banking industry.

22. Mohammad Ahmad Saqr and Buthaina Al-Muhtaseb.

Conditioning the censorial role of central banks to deal with Islamic banks. Studies (administrative sciences), vol.40, No.2,

${ }^{23}$.Jamal EddinAtiyah, Islamic banks between theory and practice. Al- Ummah, No. 57, 1405 H, P65.
} 
rates are imposed on big banks than the small ones considering their size and the possibility of moving out of market ${ }^{24}$. However, the central bank levies an usurious increase rate for cases of impotency of the banks that are incapable of settling their situation within the minimum limits of the statutory reserve. This increase surely constitutes an obvious imbalance in the relationship of the central bank with the Islamic bank as the banking transactions of the latter cannot accept those usurious penalties which contradict with the judgments of Islamic Sharia. Clearly, any usurious increase on its banking relationships may confuse the confidence of its clients as well as breaching the legislative rules it adheres to. Based on the aforementioned, the status of the statutory reserve imposed by the central bank can be straightened to blend with the Islamic banking work data in the following main points:

The central bank adopts legal exemption policy by releasing the investment deposits at the Islamic bank from the accounts and restrictions of the statutory reserve, as those deposits are stipulated on the Islamic bank by clients to be used in productive domains and profitable projects and not to deactivate utilizing them to cover the needs of the statutory reserve ${ }^{25}$.

Not to oblige the Islamic bank to any requirements for the statutory reserve except in less rates than other traditional banks considering the possibility of reducing the reserve rate for the small banks and time deposits. This is measure should be performed through understanding the rule of sheep Bagram and the suitable mechanism. The central bank still does not compromise accepting the usurious excess occurred upon its contribution in the monetary reserve.

- $\quad$ Not applying penal interest rate on the Islamic bank in case of not paying the minimum statutory reserve requirements and replacing it with a fine system connected to the size of excess ${ }^{26}$ in accordance to the non-usurious work of the Islamic bank.

Reclassifying the Islamic bank within the scope of Islamic banks not the commercial banks whereupon the new format acquires the developmental concept that contributes in multi-objectived projects adding to that the banking work does not depend on the monetary exchange which is based on usury ${ }^{27}$. This supports the idea of not affecting the monetary offer by the Islamic bank the same as other commercial banks that depend on prompt profit, fast monetary cashing and influencing the monetary offer. Consequently, the reclassification of the Islamic bank according to such data helps in finding facilities when dealing with it in applying the statutory reserve policy due to its weak impact on monetary offer.

- $\quad$ The Islamic bank ought to standardize its banking operations in terms of size of deposits, patterns of short-term and medium-term investments, controlling credit policy and dealing with financial markets and the like, and linking all those variables to the

\footnotetext{
${ }^{24}$. BarySeagal, Money, banks and economy. Translated by Taha Mansour and companion. Riyadh, Dar AlMareekh P265-266.

${ }^{25}$. BabkrMuhiddeenkili, The Relationship of the central bank with Islamic banks. Ibid, P17.

${ }^{26}$. Islamic thought board in Pakistan: Cancelling interest from economy. Translated by Abdul-Halim Assayed Munsi ed.2. King Abdul-Aziz University. The international center for Islamic economy researches, Series of Arabic publishing's: (7), 1984, P80.

27. Ali Ahmad Alsalous, Modern banks transactions in the light of Islamic.ed.1, Doha, Dar Al-Haramein for printing and publishing, 1983, P 74.
} 
ability of the bank to legally commit to the minimum limit of reserve to prevent falling in the problems of usurious excess.

\subsection{The relation of statutory reserve with zakat}

The application of the statutory reserve minimum rate by the central bank leads to many problems with the Islamic bank, most importantly, the connection of this reserve with Zakat and deactivating its utility, as the Islamic bank practically is not prepared to deduct any zakat rate from the statutory reserve because it is bonded and unproductive money which does not realize any income or economic return to its owners. This might be considered as an illogical operation through the perspective of the Islamic bank. This is because cutting the zakat rate from the reserve means a continuous corrosion to the inoperative capital and this may lead to an assertor loss in the total value of the capital through two sides: The first is that the capital deposited as a reserve cannot be used in participation, Murabaha or any possible productive operation, and secondly, it is a disabled Capital from making any potential profits for shareholders and depositors. Therefore, the Islamic bank, through sharia control mechanisms, resorts to taking Fatwas Based on Sharia licenses, or rather, taking permissive attitudes in this aspect to override the problem of paying zakat. This trend is clarified according to many justifications the most important of which ${ }^{28}$ :

- Zakat is not imposed on joint quorum.

- A partner is not allowed to pay zakat for his partner without his permission.

$\circ \quad$ The Islamic bank does not fully own the reserve. This reserve is treated as deposits assigned for a special purpose.

$\circ \quad$ The act of Uthman as a reference. When Uthman- the third pious caliph-saw the abundance of money in his age, he realized that subjecting it to zakat would harm the owners, so he authorized the owners to pay the zakat as agents for the competent authority.

These justifications and excuses are not legal but only conditioning to fill the gap between legal censorship and sharia censorship. This could be an attempt to pass over an obvious problem through legal exits that need comprehensive understanding. This can be clarified with the following points:

1) Jurists discussed whether zakat was mandatory on joint quorum as incorporated in the field of mixture.

This means the joint ownership of animals for more than one person. The Shafi'ies measures the mixture of animals to the mixture of plants and fruits and even the mixture of money ${ }^{29}$. Consequently, paying zakat of joint money is affected by the change in shares because joint quorum is treated as one unit which obliges the partner to pay the zakat of his partner as the money here pours in one zakat channel.

2) Stating that the reserve is a kind of trust for others and that it is not owned by the Islamic bank is contrary to reality as the reserve is a monetary guarantee against any possible risks that may face the individuals' deposits, that is, it plays a functional role in favor of the banking activity for all its assigned operations. Even if the reserve was considered a kind of trust, it would be as monetary trusts that cannot be utilized in productive field and go within the domain of accumulation that zakat should be taken from and this pushes the owner to invest it rather than holding it. It is well known that the

\footnotetext{
28. Abdul-Hamid Al-Sa'eh, Sharia Fatwa. Vol.2, Jordan Islamic bank, informational bulletin, No (6), 1987, P15.

29. Yahyah Bin Sharaf Al- Nawawi, Rawdat Al-Talibeen, Beirut, Islamic office, n.d. 2/ $172-173$.
} 
deactivated property loses (\%25) of its total value when you pay zakat for (12) years and loses $(\% 90)$ of its value in $(100)$ years ${ }^{30}$.

The Islamic bank should try to place methodological bases to reshape the contracting with the central bank about the legality of using the reserve according to different investment forms and admitting the uselessness of holding and deactivating the money of others and this will join efforts to solve an existing problem instead of seeking accommodative exits for this purpose.

3) As for taking the behavior of Uthman as an excuse, this could be responded to with the following points:

- $\quad$ The possible harm that could have affected money owners because of zakat at that time is unlikely to take place at present because of the accuracy of accounting procedures and the feasibility to access the financial records of those who should be charged zakat.

- $\quad$ The behavior ofUthman was acceptable in his time as he trusted people in paying zakat because they were aware of the penalty of holding zakat especially in the era of Abu Bakr- The first pious caliph- who fought against those who prevented zakat saying, "By God, if they held even a tether which they used to pay to the messenger of God, I would fight them for it" ${ }^{31}$

- $\quad$ It is also know that people - at that time - were more well- conscience than people of our time because they were more committed to the teachings of Islam and closer to the prophet's era.

- Uthman did not set the issue as a rule, he just differentiated between the inward and outward funds. He did not assign the collection of outward funds to people as the task was not difficult to do. However, the behavior ofUthman remains a personal effort suitable for that era.

Based on the aforementioned, the Islamic bank has to reconsider the issue of zakat related to the bonded reserves and to deduct the assigned zakat rate ${ }^{32}$, putting into consideration that distributing zakat is subject to the rules of zakat Fund related to the Islamic bank. Zakat money may be subject to sharia investment aspects under the supervision of the Islamic bank and to be employed in wide ranged productive projects to achieve higher profits for deservers according to their shares.

\subsection{Statutory Reserve and Due Usurious Increase}

It is well known that the statutory reserve at the central bank produces usurious surplus in favor of the Islamic bank. Most Islamic banks abstain from taking or utilizing this usurious surplus as they do not take or give usury. Here, an inquiry may be placed about the accordance of this attitude with the Islamic bank's objectives in realizing social development to people, and which is better? Using this surplus in solving social problems such as poverty according to a modern juristic perspective or to stand at the face meaning of texts without tracking the relevant surrounding aspects?

Conditioning this matter according to the contemporary social situations needs many Comprehensive sharia Considerations, and it requires a scientific effort by sharia

\footnotetext{
30. Mohammad Kahf, Islamic Economy.ed.1. Kuwait, Dar Al - galam, 1979 P 118.

31. M. Bin Ali Al-Shokani, Nail Al-Awtar, Mustafa Al-Babi Al-Halabi, n.d. 4/119. 32. Abdul-Same e' Al- Masri, why did God forbid usury? .ed.1, Cairo, wahbeh library, 1987, P 97.
} 
censorship bodies subsequent to the Islamic bank's system. The decision of taking usury to be distributed in beneficial domains or not to take it is subject to many principles and standards, the most important of which may be:

\section{First: Observing the legitimate purposes:}

Taking the haram (for bidden) because of necessity, which lines with the legitimate purposes cannot be denied. In this sense, Al- Ghazali says in Shifa' Al - Ghalil: "If someone says: when Haram becomes a necessity needed by interest, should people take only what they need from that Haram for their benefit?.... we say: If this happens ....each one may increase it as needed, and this applies on food, clothes and living places, because if they take only what keeps them alive, interests will be disrupted and the system will break down, and people will continue to suffer until they perish. This will destroy religion and undermine the rites of Islam ... It is an obvious interest and Sharia should undoubtedly consider it" ${ }^{\text {"33. }}$

\section{Second: Observing the legitimate rules:}

Here, the legitimate rules should be observed as a whole in addition to applying them in the frame of facts and evidences that produce welfare to society like: "Behaving over the subjects should be tied to benefit", "Harm is removed", "The most severe harm is removed by the less severe harm", "Necessity permits the forbidden" and "Neediness takes the level of necessity" and other similar overall rules ${ }^{34}$.

\section{Third: Observing reality and custom:}

The central bank represents a censorial authority related to the State. The attitude of the Islamic bank in rejecting the usurious surplus of its reserve deposits entitles the automatic transformation of this surplus to the general treasury of the state. On the other hand, the state is responsible for providing the minimum limits of food, clothes and accommodation for the poor ${ }^{35}$, in addition to other necessities like health, educational and security care.

Therefore, if the rights of the poor were taken away from them by the competent authorities, it is doubtless that the transformation of the usurious surplus to the state by the Islamic bank means dedicating the principle of injustice, supporting the oppressor and depriving the poor.

In this respect, it should be pointed out that all the relevant issues to the usurious surplus of the statutory reserve could be applied to any other usurious surplus due to the Islamic bank such as the usurious surplus of the monetary credits deposited at the central bank by the Islamic bank. This happens when the Islamic bank gets extra cash or deposits that cannot be assimilated within its available investment channels, so it deposits them in the form of trusts at the central bank which in turn employs them to produce usurious surplus in favor of the Islamic bank. In this respect, the Islamic bank should play an effective role

\footnotetext{
${ }^{33}$. Abu Hamed Al- Ghazali, Shifa' Al- Ghalil, ibid, P 246.

34. Abdul-KarimZeidan, Introduction to studying the Islamic sharia, ed. 9, Beirut, Al-Risalah foundation, 1986, P97-100

35. Ali Bin Ahmad IbnHazm, Almahali, investigation of Arab legacy revival committee. Beirute. Dar Al-Afaq AlJadidah, n.d 6/156.
} 
to solve this problematic relation with the central bank concerning the usurious surplus and to participate in solving the social problems and human development issues.

\section{4. conditioning the functions of the central bank with the Islamic bank's policy} Includes three subjects:

First subject: The function of the lender of last resort.

Second subject: Discount rate policy.

Third subject: Open market operations.

\subsection{The function of the lender of last resort}

The central bank plays the role of the lender of last resort according to what is called "discount window", so it raises or lowers the discount rate on the granted loans in harmony with its inclination towards promoting banking borrowing ${ }^{36}$. Mostly, the central bank interferes as a last resort lender to straighten some forms of financing impotence especially when the banking policy of some banks gets out of control. This type of incidental long term loans allow the flow of extra reserve to face the realized incapacity or potential risks ${ }^{37}$.

Undoubtedly, there are problems related to the function of the central bank as last resort lender. The bank faces those problems in the frame of its relationship with the Islamic bank whereupon the Islamic bank cannot support its difficult attitudes in the field of cash and credit by utilizing the granted loans which are connected to usurious discount rates. This makes the Islamic bank resort to contracting banking procedures to face any potential risks. From those procedures are ${ }^{38}$ :

1) Directing investment and deposit employment policies to short and medium term financing periods.

2) Maintaining high percentage of cash ready to face emergencies as well as using it in productive investment fields to realize high returns for depositors.

3) Limiting the policy of financing investments and to be satisfied with investment styles like Murabaha because of their fast monetization and clear proceeds.

Some methods can be suggested to solve the problem of the last lender without following the financing methods based on usurious discount, as a policy to condition the Islamic banking work with the central bank's mechanisms. Of those methods are:

- $\quad$ Establishing a banking portfolio through the contribution of Islamic banks with a certain rate of their deposits at the central bank forming one deposit that would be granted by the central bank to any Islamic bank that faces risks and problems ${ }^{39}$. This mechanism can be generalized locally or in a crossing frame according to the work mechanism, contribution opportunity and possible economic feasibility.

- The central bank to adopt the principle of participating in gains and losses, and to apply the preferential sharing rate of the sectors of priority instead of the preferential discount rates ${ }^{40}$. In addition, the central bank ought to deal with the Islamic bank according to the possible legitimate methods such as speculation, where the central bank plays the role of capital owner and the Islamic bank represents the speculator.

\footnotetext{
${ }^{36}$. Suzan Lee, The Alphabet of Economy. Translated by khidrNassar Jordan book center, 1988, P83.

37. Segal Bary: Money, Banks and Economy, translated by Taha Mansour and Companion. Riyadh, Dar AlMareekh. N.d P257

38. Musa Abdul-Aziz Shihadeh. "Plan for Islamic banks Investment Strategy". Sixth annual conference of the Royal Society for Research on Islamic Civilization, 1987, P28.

39. Ismael Hasan, work paper about the relationship of the central bank with Islamic banks, ibid, P33.

${ }^{40}$. Baker MuhiddenKili, the relationship of the central bank with Islamic banks. Ibid, P19.
} 
Here, the Islamic bank plays the role of mediator as it does not usually work by itself but originally represents a financial mediator. Jurists allowed the representation of speculator as financial mediator by transferring the capital to another speculator and provided that in order for the first speculator (the Islamic bank) to be able to play the role of mediator; it should obtain general authorization or special clear permission from the owner of the money ${ }^{41}$.

- $\quad$ Dealing with a banking entity that acts on behalf of an international Islamic bank and plays the role of the lender of last resort according to the Islamic legislation, through the membership of the Islamic banks wherever they were, and without considering the advantages of one region. This mechanism realizes some important advantages of which:

a) Achieving high monetary surplus generated through the participation of Islamic banks in this entity which produces a state of integration to face any disability cases in the Islamic banks that encounter shortage in liquidity ${ }^{42}$.

b) The attempt of convergence in the credit policy of Islamic banks which contributes in avoiding the fall in the financing disability problems or executing wrong credit policies ${ }^{43}$.

c) Constructing a financial block with international banking weight which helps Islamic banks to control the flow of money among the Islamic countries and open significant opportunities through which the Islamic banks will be able to play a role similar to that of the rich ten western countries that control the activities of the international financial markets ${ }^{44}$.

\subsection{Discount Rate policy}

Practicing the principle of discount rate provides the traditional banks with many opportunities to get loans from the central bank. They especially utilize them when those banks face loss in reserves, sudden increase in withdrawals or the disability to collect cash in the monetary market. The mechanism of discount rate takes place in the frame of statutory censorship practiced by the central bank to control the monetary base. For this reason, the central bank takes precautions when following this measure by recognizing the background, debts and reserve of the borrowing bank as well as any other factors that may affect its monetary status ${ }^{45}$.

Moreover, the central bank applies the discount rate mechanism according to the prevalent situation of the market. For example, the central bank applies a simple interest margin during economic expansion, and such measures are acceptable and logical under the expected privileges and returns on the level of national economy.

In the frame of the Islamic bank's relationship with the central bank, there is no acceptable benefit that results in applying the discount rate policy. If this policy, for instance, moved towards conditioning investment in certain sectors, encouraging exports of specific commodity or directing production to attract hard currency, the Islamic bank would not get benefit from the granted facilities through the discount rate policy to achieve those

\footnotetext{
${ }^{41}$. Alaa' Eddeen Al-Kasani, marvelous creations in ordering legislations. Cairo, scientific pubications co. n.d., $7 / 95$

42. M. Abdul-Hakim Za'ir, International Islamic bank. Islamic Economy, No. 29, 1984, P 2-3.

${ }^{43}$. M. FawziHamzeh, Islamic monetary area and the Islamic central bank. Nation, No. 54, 1985, P4.

${ }^{44}$. Ibid, same page.

${ }^{45}$. Barysegal, money, banks and economy. Ibid, P256-257.
} 
goals. This is because the discount rate policy runs through usurious channels which negatively reflects upon both the Islamic bank and the central bank.

The Islamic bank cannot export goods except with new doubled costs for clients ${ }^{46}$, which reduces real competition chances against traditional banks. As for the central bank, its reliance on the principle of usurious surplus in the discount policy could limit the optimal use of the monetary policy tools because the Islamic bank represents an effective and influential financial and monetary power on the level of the banking system as a whole thanks to its fluidity surplus which the usurious surplus policy does not allow using or utilizing.

The central bank's mechanism can be conditioned to deal with the provisions of the Islamic banking work like participating in the gains and losses instead of the discount rate mechanism and also ${ }^{47}$ by applying sharing formula that replaces the minimum and maximum limits of the interest rates with the minimum and maximum limits of the gains and losses ratios. Consequently, the deposits and transfers granted to the Islamic bank go into the investment mechanism which is in turn subject to again and $\operatorname{loss}^{2}$. The profits of participation operations can be distributed on the basis of controlling the size of management premium. This premium means that part of the gains distributed in the participation agreement between the central bank and the Islamic bank is cut as a reward for business management, or what is called investment function and the remaining part is distributed between the two parties according to capital ${ }^{48}$.

The effect of the central bank's participation is determined on the grounds of participation in the same method created by the change in interest rate. Thus, the central bank adopts the policy of changing the ratios of participation in profits of the granted finances in conformity with its goals that target at controlling credit and organizing the banking finance in general ${ }^{49}$. In case of expanding the credit umbrella by the central bank, its participation will be limited on realizing less profit margin and otherwise increases profit margin and consequently, the net margin of profit achieved by the Islamic bank is affected, and this contributes in controlling its finances and the domain of its participation in creating the desired credit. In this case, the central bank can adapt with the credit policy by using the approach of preferential participation in specified sectors as well as confining the flow of financing to undesirable sectors. All this depends on the requirements of adjusting credit and controlling the ratio of financing fluidity.

In addition, the central bank can adopt the speculation formula instead of the discount rate policy with the Islamic bank, and in this case, if it wanted to reduce the size of credit, it would increase the share of the Islamic bank in the profits of speculation, and the opposite in true if the central bank increased the size of credit ${ }^{50}$.

\footnotetext{
${ }^{46}$. Musa Abdul-Aziz Shihadeh, "The plan of investment strategy in the Islamic banks" ,ibid, P27.

${ }^{47}$. The Islamic thought council in Pakistan, cancelling the interest from economy, ibid, P82, 84.

48. Adnan Al-Hindi, "The relationship between central banks and Islamic banks". The Islamic banks, Beirut, Arab bank union, 1989, P 29

${ }^{49}$. BabkerMuhiddeenKili, the relationship of the central bank with Islamic banks. ibid ,P 18-19.

${ }^{50}$. Adnan Al-Hindi, "The relationship between central banks and Islamic banks" . ibid, P29.
} 


\subsection{Open Market Operations}

By using the open market operations, the central bank aims at controlling the monetary market and observing the circumstances of economy and the market in general, and no doubt that these operations line with the overall policy of the state and agree with the national development plans concerning the realization of the economic expansion, revival or contraction goals, which ultimately contribute to arrive at welfare levels.

Central banks usually use open market operations as a tool of monetary policy which means selling and buying securities, and most importantly governmental stocks to influence size of monetary offer according to the prevalent economic situations.

As a procedure; and in case of inflation, which is increasing rise in prices, the central bank resorts to selling stocks because of the tension of natural currency and absorbing it from the monetary base leading to the rise of interest rates and contraction of credit. This moves the demand towards the decrease of prices ${ }^{51}$. However, in Case of unemployment, this operation is reversed, as the central bank buys stocks to increase the monetary offer, decrease interest and move the demand to the direction that achieves higher rates in prices. This means that the central bank has the capacity to straighten the monetary situation through quick responses in the market operations' indicators. Obviously, open market operations move off adhering sharia rules to another frame that contradicts those rules, and which is based on exchanging stocks. This is because stocks represent a form of loan contract and carry fixed interest (usurious surplus) of their nominal value transforming them to a form of usurious loans and this leads to the invalidity of the contract and the prevention of their issue or exchange in selling or buying ${ }^{52}$.

Hence, the relationship of the Islamic bank with the central bank becomes incorrect from the perspective of Sharia because the Islamic bank's methods do not agree dealing with usury whether taking or giving. This simply means that the monetary instrument comes into the banking disorders in the frame of relationship which requires finding an appropriate legislative replacement.

One of the suggested alternatives to treat the problem of dealing with stocks is that the central bank may issue different securities based on sharing profits and losses in the form of vouchers that have changing profit rates in place of the stocks that have fixed usurious surplus.

The replacement of the fixed interests of stocks with the changing profits of vouchers provides the Islamic bank with a better opportunity to participate in the central bank's procedures and the monetary policy goals. This is because the Islamic bank enjoys high rate of liquidity which opens the way to perform an important role in dealing with market operations and reaching better levels than those of the objectives of the monetary policy.

By applying the idea of Changing profit vouchers, the central bank Can achieve its monetary purposes and control the size of monetary offer it desires. For its policy that aims at reducing the level of monetary offer, the central bank has to determine less profit

${ }^{51}$. Edwen, Mansfield, Econoy, Jordan book center, 1988, P 254.

52. Ali Ahamad Al - Salous, Modern banks transactions in the light of Islam , ibid. P $85-86$. 
rates in selling the vouchers, so its participation will be less and its ability to absorb the savings and reducing the monetary offer will be greater.

In case of buying, it can determine profit rates through larger participation which expands and increases the size of monetary offer and achieves wider ranges for credit. Through this mechanism, the central bank contributes in treating the gap of liquidity surplus at the Islamic bank and prepares a more positive banking climate for all the monetary centers and financial institutions in the market as well as producing an effective and fruitful domain for the Islamic bank to practice its banking operations in accordance with legislative rules, take its natural situation and confirm its role and existence in the market.

\section{Conclusion}

The most important results and recommendations of the research can be stated in the following Points:

\section{First: Results:}

1. The interference of the central bank in the banking activity represents the state's sovereignty which is originally practiced to observe the general interests and consequently, this interference is not regarded as transposing the freedom of individuals and their rights in directing their investments and deposits unless Contradicting sharia in Keeping the money and developing it, or losing the ability to condition its relationship with the Islamic bank on the basis of protecting the exchanges from usury.

2. The treasury (Bait Almal) of the Islamic state represents a similar image to an Islamic central bank because of the similarity in some of the duties performed by the central bank in its contemporary form.

3. The basic difference in the relationship between the Islamic bank and the central bank is the Contradiction between censorships: The legal censorship of the central bank which is derived from the positive law and the legislative censorship of the Islamic bank which is derived from Islamic Sharia.

4. The essential change related to the situation of the Islamic banking establishment needs on extensive reordering according to new frames and structures that cope with the integrative presentation of Islam and avoid the organizational containers inspired by the structures of usurious institutions.

5. The Islamic bank can play the role of medial speculator as an attempt to treat its relationship with the central bank as lender of last resort.

6. The central bank is able to adopt the principle of participating in gains and losses instead of applying the discount rate mechanism. It can also, by determining the minimum and maximum profit rates, create the required effect in the volume of credit and monetary offer, in a similar pattern of the impact of changing the interest rate.

Second: Recommendations:

1. Reclassifying the Islamic bank among the central banks as non - commercial Islamic banks because it practices its work on the basis of participation and within relatively long periods and does not aim at quick profits which lessens its impact on the monetary offer.

2. The necessity of performing monetary procedures by the central bank to limit the disorder in the minimum monetary reserve through exempting the investment deposits, lessening the reserve rate and not applying penal interest rate.

3. The Islamic bank should pay Zakat from the statutory reserve deposits at the central bank because they are deactivated money which Islam urged to invest. They also contribute in credit coverage. The Islamic bank should also seek to find other solutions with the central bank to develop this money to achieve returns for owners. 
4. The Islamic bank is to collect the usurious surplus deserved for its monetary reserve and distribute it on the poor according to the statements of jurists about the necessity of caring for the poor in the basic needs of living. This thought is enhanced by the fact that the state is responsible for attending the poor and the poor are deprived from this right, the Islamic bank should be strict in distributing the usurious surplus on the poor instead of keeping it at the central bank because this means providing help to injustice and depravation.

5. The central bank is to depend on securities that have vouchers with changing profits to face the imbalance which the Islamic bank in operations in with the central bank depends on dealing with stocks with usurious increase. Here, the central bank can affect the monetary market according to the ratio of its participation in profits in the cases of selling and buying.

\section{References:}

- Jordan central Bank: Research and studies department, special edition, October, 1989.

- $\quad$ Ibn Ham, Ali Bin Ahmad. Al - Mahla. Editted the Arab legacy revival Committee, Beirut, Dar Al - Afaaq Al - Jadidah, n.d.

- $\quad$ Hasan, Ismael, Work - paper about the relationship of the central bank with Islamic banks, Islamic economy No. 46, 1985.

- $\quad$ Hamzeh, M. Fawzi, The Islamic monetary area and the Islamic central bank. Nation, No. 1985.

- $\quad$ Al - Khalifah, M. Uthman. "The banking model in Sudan between the non usurious institution and the integral Islamic institution". Faith Research Journal, Y2, No.2, 1996.

- $\quad$ Ridy, Rizk. The Arab Society in the phase of change. Translated by Ahmad Abdul Aziz Annajjar, ed.1, Sudani House, 1970.

- Za'eer, M. Abdul Hakeem, International Islamic bank, Islamic Economy, No. 29, 1984.

- $\quad$ Zaidan, Abdul - Kareem, An introduction studying the Islamic Legislation. Ed, Beirut, Al - Risalah institution, 1986.

- $\quad \mathrm{Al}$ - Salous, Ali Ahmad, Modern Banks Transactions in the light of Islam, ed, Doha, Dar Al - Haramein for printing, 1983.

- $\quad$ Segal, Bary. Money and Economy. Translated by Taha Mansour. Riyadh, Dar Al - Mareekh, n.d.

- $\quad \mathrm{Al}$ - Sa'ah, Abdul Hameed. Legal Fatwa, V01.2, Jordan the Islamic bank, informative bulliten, No. (6), 1987.

- $\quad$ Shihadeh, Musa Abdul Aziz. "strategic investment plan in Islamic banks", sixth annual conference of the royal society for research and Islamic civilization, 1987.

- $\quad \mathrm{Al}-$ Shokani, M. Bin Ali. Attaining purposes. Mustafa Albabi Al - Halabi, n.d.

- $\quad$ Sakr, M. Ahmad, and Buthaina Al - Muhtaseb, Conditioning the censorial role of central banks to deal with Islamic banks.studies (managerial Sciences), V01.40, No. 2, 2013.

- $\quad$ AssayadAhamad. Risk Management in Islamic banks, Conference of risk management in Islamic banks, Amman, Arab Academy for financial and banking sciences, 2004.

- $\quad \mathrm{Al}$ - Dahian, Abdul - Rahman Bin Ibrahim, management, and governance in Islamic thought and practice. Ed.3. n.d.,Kingdom of Saudi Arabia.

- $\quad$ Atyah, Jamal Eddin, Islamic banks between theory and practice, Nation, No. 57, $1405 \mathrm{H}$. 
- $\quad$ Al - Ghazali, Abu Hamed. Shif' Al - Ghalil. Hamad Al - Kubaisi. Ed.1, Baghdad, Al - Irshad press, 1971.

- $\quad$ Fredman, Miltion. Capitalism and Freedom, transdom, translated by YusefElayan. Jordan book center, 1987.

- $\quad$ Kahf, Mohammad, Islamic Economy. Ed.1, Kuwait, Dar Al - qalam, 1979.

- Kili, BabkrMuhiddeen, the relationship of the central bank with Islamic banks, Money and Economy, No.3, 1986.

- $\quad$ Kala'aw, Ghassan, Islamic Banks: Modern necessity, why? Beirut, Dar Al Maktabi, 1998.

- $\mathrm{Al}$ - Kassani, Alaa' Eddin, great creations in ordering legislations Cairo, scientific publishing co., n.d.

- $\quad$ Lee, Suzan. The Alphabot of Economy. translated by KhudrNassar. Jordan book center, 1488 .

- $\quad$ Mansfield, Edwin, Economy. Jordan book center, 1988.

- Islamic thought board in Bakistan: cancelling interest from economy, tran slated by Abdul - Halim Assayed Minsi, ed.2, King Abdul Aziz university, the international center for Islamic economy researches, Arab prints series: (7), 1984.

- $\quad \mathrm{Al}$ - Masri, Abdilsamee', why did God prevent usury? ed.1. Cairo, wahbeh library, 1987.

- $\quad \mathrm{Al}$ - Masri, Rafeeq. The Islamic development bank. Ed.3, Beirut, Al - Risalah institution, 1987.

- $\quad$ Milhem, Ahmad Salem Abdullah, Muraha Sale. Ed.1, Amman, Al - Risalah library, 1989.

- $\quad \mathrm{Al}$ - Nabhan, M. Farouk. Researches in Islamic economy, ed.1, Beirut, Al Risalah foundation, 1986.

- $\quad \quad \quad A l$ - Nawawi, yahya bin sharaf, RawdatAtttalibeen, Berut, Islamic office, n.d.

- $\quad \mathrm{Al}$ - Hindi, Adnan, "The relationship between the central banks and the Islamic banks". Islamic banks, Beirut, Arab banks Union, 1989.

- Jean - Claude Trichet: Global Gobal governance today, BIS Review 56 / 2010.

- Revine I. Collins. Financial Reporting and analysis New Jersey. 2005. 